\title{
Moral emotions, conscience, and cognitive dissonance
}

\author{
Gershon M. Breslavs
}

Baltic Psychology and Management University College, Latvia, Riga

\begin{abstract}
One of the central topics in the studies of O. K. Tikhomirov and his collaborators was the link between cognitive and emotional processes. It is important not only how emotions are involved in the process of the productive performance of thinking tasks but also how cognitive processes mediate the involvement of the emotions in the regulation of activity. The efficacy of this regulation is represented through goal achievement and also through the correction of one's actions in the case of wrongdoing. Reformation of one's errors is the best way to improve one's abilities and skills. In moral philosophy the central instance of this reformation is conscience, which ensures positive or negative self-appraisal of one's own and others' actions. Unfortunately, in psychology this concept remains unclear. The goal of this article is to clarify it in the context of the contemporary psychology of emotion. Studies of emotions have shown the significance of appraisal in determining particular feelings. The special role of moral emotions, mainly guilt and shame, in the self-correction of one's actions is emphasized. According to this model, guilt and shame in particular can represent twinges of conscience in the mind because the cognitive dissonance between our (or others') actions and values shapes the basis of all these phenomena.
\end{abstract}

Keywords: moral emotions, conscience, guilt, shame, cognitive dissonance

Tikhomirov's and his colleagues' works revealed complicated emotional regulation of the performance of intellectual tasks (Tikhomirov, 1984). This regulation seems to be in the field of the self-correction of transgressions. Despite the improvement of technological resources in contemporary human society, the amount of intolerance, discrimination, and violence has not diminished. More conservative people see the solution of these problems in the development of the penitentiary system, from sanctions imposed on parents to criminal sanctions. Liberally oriented people see the solution in the humanization of family and school upbringing. In turn, good nurturance and upbringing can be viewed as successful only if people are able to autonomously correct their mistakes and improve their bjehavior. This ability essentially is described as conscience.

The American Psychological Association's definition of conscience is "an individual's sense of right and wrong. In psychoanalysis, conscience is the SUPEREGO, or ethical component of personality, which acts as judge and critic of one's 
actions and attitudes" (APA Dictionary of Psychology, 2007, p. 218). Changing ethical to inner and adding the estimation of other persons' actions, we can get a balanced definition of conscience: an inner component of personality that acts as judge and critic of one's own and others' actions according to one's values. This definition is in agreement with Freud's and Allport's descriptions (Allport, 1955; Freud, 1923/1968). In contemporary psychology the closest construct to conscience seems to be self-control of social behavior. Its function is signaling an important discrepancy or a gap between our social behavior, on the one hand, and our values, goals, and beliefs, on the other. According to psychoanalytical and socio-cultural approaches, this self-control grows through the internalization of social (first of all, parents') control (Freud, 1923/1968; Mead, 1934; Vygotsky, 1984).

However, how can we be sure that twinges of conscience or the feeling of remorse really exist? Sometimes self-reports represent desired rather than real experience and feeling. Given the essence of self-control, we can expect that the coherence of our social behavior with our aspirations and expectations leads to a feeling of pride, while incoherence leads to feelings of shame and guilt. Many studies in the field show that the most reliable expressions of twinges of conscience are moral emotions, especially shame and guilt (Barret, 1995; de Hooge, Zeelenberg, \& Breugelmans, 2010; Lewis, Sullivan, Stanger, \& Weiss, 1999). Some authors consider twinges of conscience to be an obligatory element of guilt (Tangney, Stuewig, \& Hafez, 2011). The common reason for both these emotions is the discrepancy (cognitive dissonance) between one's actual behavior (or unjustified lack of activity) and the wish to conform to one's desired self-image and values. The subject of these emotions can be not only oneself but any member of one's group (from a relative to a compatriot).

The differences between shame and guilt should be discussed. Shame is expressed clearly: flushed face, ears, and neck; averted or sunken head; closed face or eyes; interrupted communication; avoidance of the witnesses of a transgression. Guilt is not expressed so obviously. Shame is impossible without a real or imagined audience that is critical of the agent of a transgression. One is shamed or blamed by somebody in one's consciousness. Guilt is more oriented toward the victim of a transgression but not to betrayals. A person who has guilt feelings cares not about an observer's assessment of the deed but about the consequences of the transgression. In the case of my wrongdoing the cognitive content of shame is focused mainly on my own self ("I am bad") but the cognitive content of guilt is differentiated from myself and is focused on my particular actions only ("I was wrong in this situation") (Tangney, 1995).

Some researchers consider that guilt is based on empathy with real or imagined victims of our activity (or on passivity) and presupposes concerns about issues connected with the direct or indirect responsibility for infliction of harm (Olthof, 2012; Olthof, Ferguson, Bloemers, \& Deij, 2004). Hoffman (1982) proposed a differentiation of guilt and shame based on their consequences: namely, guilt promotes reparative behavior and an increase in motivation to communicate, whereas shame leads to withdrawal and a decrease in this motivation. Meta-analysis has shown that the feeling of guilt is related to the development of conscience in children and to conscientious behavior in young adults (Dost \& Yagmurlu, 2008). Table 1 summarizes the differences between shame and guilt. 
Table 1. Differences between shame and guilt

\begin{tabular}{lll}
\hline & \multicolumn{1}{c}{ Shame } & \multicolumn{1}{c}{ Guilt } \\
\hline $\begin{array}{l}\text { Cognitive content } \\
\text { Focus of feeling and } \\
\text { cognition }\end{array}$ & «I am bad» negative identity & $\begin{array}{l}\text { «I did it badly» wrongdoing } \\
\text { On the victim and on com- } \\
\text { pensation for the infliction of } \\
\text { harm }\end{array}$ \\
$\begin{array}{l}\text { Duration } \\
\text { Links with the situation } \\
\text { of the transgression }\end{array}$ & $\begin{array}{l}\text { Field dependence (concerns about } \\
\text { others' opinions) }\end{array}$ & $\begin{array}{l}\text { Long-term } \\
\text { Expression }\end{array}$ \\
$\begin{array}{l}\text { Flushed face, ears, and neck; } \\
\text { averted or sunken head; closed } \\
\text { face or eyes; interrupted commu- } \\
\text { nication }\end{array}$ & $\begin{array}{l}\text { No constant pattern } \\
\text { Possible consequences }\end{array}$ \\
$\begin{array}{l}\text { Social acceptance, desire to impro- } \\
\text { ve one's image } \\
\text { Social avoidance, feelings of inferi- } \\
\text { ority and loneliness, social anxiety, } \\
\text { hostility, and aggression }\end{array}$ & $\begin{array}{l}\text { Social approach, inclination to } \\
\text { tion, depression }\end{array}$ \\
\hline
\end{tabular}

Lewis considered individual differences in affective style depending on preferences to feel shame or guilt in appropriate situations of moral transgression (Lewis, 1971). These differences, in their turn, lead to different types of dysfunctions. Inclination to shame is linked to vulnerability to affective dysfunctions (depression, anger, narcissism), but inclination to guilt is linked to vulnerability to cognitive dysfunctions (paranoia, obsessive -compulsive disorders).

At the same time, we should take into account that a long-term feeling of guilt leads to depression. Zahn-Waxler discussed adaptive guilt as an action-oriented, conscious feeling accompanied by making reparations and helping others, and maladaptive guilt as an excessive, self-critical feeling accompanied by a sense of responsibility for everything that goes wrong (Zahn-Waxler, \& Kochanska, 1990). Some scales have been elaborated for the measurement of long-term or chronic feelings of guilt (Harder, Cutler, \& Rockart, 1992; Kugler \& Jones, 1992). When one widens the zone of one's activities, criticism increases the probability of fixation on negative self-image, self-condemnation, and self-punishment. Research data from a sample of college students showed no significant link between experiencing predispositional guilt and psychological problems such as those with somatic, obsessivecompulsive, anxious, and paranoid symptoms; but they did show a positive link between chronic guilt and these symptoms, including depression (Quiles \& Bybee, 1997). Taking into account the longer duration and larger depth of guilt, it is understandable that patients with strong depression show higher correlations with guilt than with shame (Alexander, Brewin, Vearnals, Wolff, \& Leff, 1999). Relatives of schizophrenic patients demonstrated a guilty conscience (negative self-esteem, because of their belief that they were morally wrong, and self-condemnation), which was positively linked with their depression, suffering, and failure to cope with these 
feelings (Boye, Bentsen, \& Malt, 2002). In other words, the feeling of guilt did not help but rather shaped in these relatives a neurotic circle.

A functional approach to emotion leads us to an understanding of the constructive role of shame too. The expression of shame is a good signal of the negative estimation of one's behavior and the readiness to eliminate such socially unattractive behavior. These signals can prevent others' aggression (Ferguson, 2005; Gilbert \& McGuire, 1998). Acceptance of one's wrongdoing together with elements of the expression of shame leads to the appeasement of the injured party and forgiveness (Keltner \& Harker, 1998). At the same time, verbal apologies, such as "I was ashamed remembering my behavior yesterday," are not always accompanied by a feeling of shame. Sometimes these phrases represent our acceptance of moral norms and not our real attitude toward a transgression.

Often the blushing of a transgressor in comparison with the neutral face of a transgressor leads to a higher appraisal from observers (Dijk, de Jong, \& Peters, 2009). The reason for such an appraisal is the perception of blushing as an involuntary, sincere reaction of the transgressor that promises a correction of behavior and the prevention of future transgressions (de Jong, 1999; Gold \& Weiner, 2000). In its turn, strong blushing shows a reaction to a possibly unpleasant perception of a person by significant observers, a perception the person finds it difficult to accept. Some researchers label this phenomenon negative identity (Ferguson, Eyre, \& Ashbaker, 2000; Olthof et al., 2004).

A person's anticipation of feeling shame or guilt can be a serious obstacle to amoral behavior (Olthof, 2012). Students' feelings of shame were negatively linked with the desire to drink or to filch in a store (Tibbetts, 1997). These data show that the feeling of shame has an adaptive function in the understanding and correction of wrong actions (Dost \& Yagmurlu, 2008). When there is a strong differentiation of shame and guilt, both emotions are negatively linked with antisocial behavior (Menesini \& Camodeca, 2008), but only the feeling of guilt can predict prosocial behavior in cases of school violence (Olthof, 2012).

Qualitative and quantitative analysis of autobiographical narratives on the feelings of shame and guilt $(N=23, \mathrm{Ma}=24.5)$, using $\chi^{2}$ of association, showed a stronger desire to improve one's image in the case of shame than in the case of guilt. The same priority in the case of shame was given to desiring to keep close or to abate, striving to escape from a situation, being concerned about others' opinions, striving to change the image of a situation. These were predicted on the basis of previous studies. In the phenomenology of guilt, the fear of not acting in accordance with one's desires and acceptance of the inadequacy of one's actions were higher than in the phenomenology of shame (Breslavs, 2007). It appears that retrospective narratives about experienced shame for particular actions can be identified as expressing the feeling of guilt, not of shame.

These data showed that, in a situation of transgression, for a feeling of shame to develop the public situation as such is not critical but the opinion of a significant observer is critical. If we believe that this observer considered our behavior a transgression, a cognitive dissonance arises. The second obligatory aspect of shame is the content of this dissonance. It is not a particular but a general dissonance between the ideal self and global self-esteem. Both aspects are interdependent (Wolf, Cohen, Panter, \& Insko, 2010), and this interdependence can be explained 
by social perception. We are able to take into account that people around us judge our image and actions quickly and superficially, sometimes using insignificant elements of our behavior. It is understandable that people are inclined to feel shame in prestigious and responsible situations (official parties, conferences, the bestowal of honors, and so forth). Transgressions in these situations can destroy a person's reputation, and emotional anticipation in the form of shame can mobilize the selfcorrection process.

Using R. Lazarus's model of two stages of cognitive appraisal, de Hooge and colleagues (2010) proposed two possible consequences of the feeling of shame: approach when the renovation of reputation is estimated as more or less possible, and avoidance when the renovation of reputation is estimated as very dangerous or impossible. If shame represents concern about one's marred reputation, the emergence of the motivation to renovate one's self-image is understandable. In its turn, the motivation to renovate one's self-image can result in mitigation-at-any-cost (self-defense), or it can be prosocial (apologies and compensation to victims). Only the prosocial version can be related to twinges of conscience.

The secondary stage of a moral transgression can be (1) condemnation by significant others or (2) understanding of one's weakness (Gausel \& Leach, 2011). The first possibility was related by Gaisel and Leach to concerns about one's social image, while the second possibility was related to concerns about self-image. Condemnation by significant others leads to avoiding contact with others and a feeling of inferiority. Understanding one's weakness has two possible results: (1) if negative self-esteem is global ("I am bad"), it results in a feeling of inferiority and avoidance of traumatic social contacts; (2) if this appraisal is specific and particular ("I have no good skills in the field"), it results in self-improvement. In these differentiations the borderline between social image and self-image remains unclear because our weakness worries us in the context of social relationships only. A mirror for us is a tool for the control of social perception as well as a tool for self-control.

How adaptive guilt and shame are depends on the subject matter and duration of these emotions (Breslav, 1977). The subject matter of shame and guilt depends on: (a) the agent of the transgression (oneself, a friend, a relative, members of one's in-group or nation); (b) the burden of the transgression (failure in sports, tardiness, a white lie, aspersion, or violence); (c) how reversible the transgression is (the availability of opportunities to correct outcomes); (d) whether the transgression is intentional or unintentional, random; (e) how particular or general the transgression is (lack of skills in a particular field or general disability); (f) who the victims and observers of the transgression are. Critical for the feeling of shame is the significance of the transgression's observers and the probable loss of reputation, while for the feeling of guilt the critical factor is the harm to the victims. Figure 1 presents a general model of these emotions.

The duration of these emotions is different and can be of adaptive value. Shame, as the more painful and expressive emotion, is a short-term feeling. When coping with cognitive dissonance through a reappraisal of the situation-for example, by the transfer of responsibility from oneself to others-shame can be changed into resentment or anger with subsequent aggression. The reappraisal of a transgression can minimize the burden of wrongdoing (for example, "it is common to all 


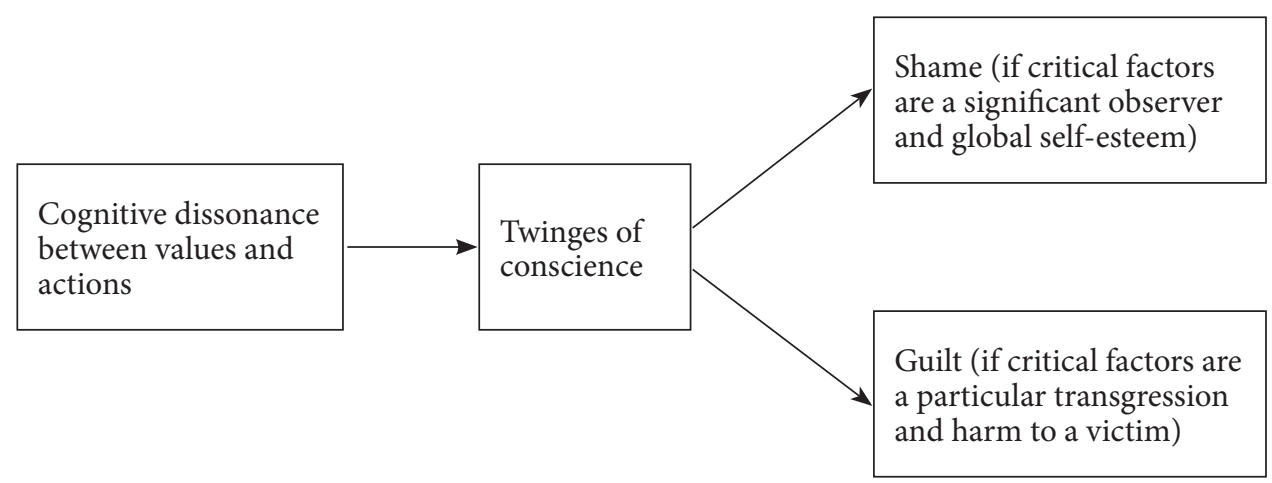

Figure 1. General model of moral emotions (guilt and shame)

people"); such minimization weakens moral emotions. If a person fails to minimize cognitive dissonance through reappraisal, shame can turn into long-lasting guilt. If this feeling of guilt does not lead to compensation for the inflicted harm-in particular, when this harm is irreversible (death or loss of health) - the outcome of the accumulation of guilt can be more destructive than the outcome of shame (Wolf et al., 2010).

\section{References}

Alexander, B., Brewin, C. R., Vearnals, S., Wolff, G., \& Leff, J. (1999). An investigation of shame and guilt in a depressed sample. British Journal of Medical Psychology, 72, 323-338. doi: $10.1348 / 000711299160031$

Allport, G. W. (1955). Becoming: Basic considerations for a psychology of personality. New Haven, CT: Yale University Press.

APA Dictionary of Psychology. (2007). G.R. VandenBos (Ed.). Washington, DC: American Psychological Association.

Barret, K. C. (1995). A functionalist approach to shame and guilt. In J. P. Tangney \& K. Fisher (Eds.), Self-conscious emotions: The psychology of shame, guilt, embarrassment, and pride (pp. 25-63). New York: Guilford Press.

Boye, B., Bentsen, H., \& Malt, U. F. (2002). Does guilt proneness predict acute and long-term distress in relatives of patients with schizophrenia? Acta Psychiatrica Scandinavia, 106, 351357. doi: 10.1034/j.1600-0447.2002.02276.x

Breslav, G.M. (1977). Predmetnostj emocionalnyh javlenij (The subject matter of emotional phenomena).Vestnik Moskovskogo universiteta. Seriya 14. Psikhologiya [Moscow University Psychology Bulletin], 4, 3-11.

Breslavs, G. (2007). Personality assessment. Unpublished manuscript.

de Hooge, I. E., Zeelenberg, M., \& Breugelmans, S. M. (2010). Restore and protect motivations following shame. Cognition \& Emotion, 24(1), 111-127. doi: 10.1080/02699930802584466

de Jong, P. J. (1999). Communicative and remedial effects of social blushing. Journal of Nonverbal Behavior, 23, 197-218. doi: 10.1023/A:1021352926675

Dijk, C., de Jong, P. J., \& Peters, M. L. (2009). Remedial values of blushing in the context of transgressions and mishaps. Emotion, 9(2), 287-291. doi: 10.1037/a0015081 
Dost, A., \& Yagmurlu, B. (2008). Constructiveness and destructiveness: Essential features of guilt and shame feelings respectively? Journal for the Theory of Social Behaviour, 38(2), 109-129. doi: $10.1111 / \mathrm{j} .1468-5914.2008 .00362 . \mathrm{x}$

Ferguson, T. J. (2005). Mapping shame and its functions in relationships. Child Maltreatment, 10, 377-386. doi: 10.1177/1077559505281430

Ferguson, T. J., Eyre, H. L., \& Ashbaker, M. (2000). Unwanted identities: A key variable in shame-anger links and gender differences in shame. Sex Roles, 42, 133-157. doi: 10.1023/ A:1007061505251

Freud, S. (1923/1968). The ego and the id. In J. Strachey (Ed. \& Trans.), The standard edition of the complete psychological works of Sigmund Freud (Vol. 19, pp. 19 -28). London: Hogarth.

Gausel, N., \& Leach, C. W. (2011). Concern for self-image and social-image in the management of moral failure: Rethinking shame. European Journal of Social Psychology, 41, 468-478. doi: 10.1002/ejsp.803

Gilbert, P., \& McGuire, M. T. (1998). Shame, status and social roles: Psychobiology and evolution. In P. Gilbert \& B. Andrews (Eds.), Shame: Interpersonal behavior, psychopathology, and culture (pp. 99-125). Oxford University Press.

Gold, J. A., \& Weiner, B. (2000). Remorse, confession, group identity, and expectances about repeating a transgression. Basic and Applied Social Psychology, 22, 291-300. doi: 10.1207/ S15324834BASP2204_3

Harder, D. W., Cutler, L., \& Rockart, L. (1992). Assessment of shame and guilt and their relationships to psychopathology. Journal of Personality Assessment, 59, 584-604. doi: 10.1207/ s15327752jpa5903_12

Hoffman, M. L. (1982). Development of prosocial motivation: Empathy and guilt. In N. Eisenberg (Ed.), Development of prosocial behavior (pp. 281-313). New York: Academic Press. doi: 10.1016/B978-0-12-234980-5.50016-X

Keltner, D., \& Harker, L. A. (1998). The forms and functions of the nonverbal signal of shame. In P. Gilbert \& B. Andrews (Eds.), Shame: Interpersonal behavior, psychopathology, and culture (pp. 78-98). New York: Oxford University Press.

Kugler, K., \& Jones, W. H. (1992). On conceptualising and assessing guilt. Journal of Personality and Social Psychology, 62, 318-327. doi: 10.1037/0022-3514.62.2.318

Lewis, H. B. (1971). Shame and guilt in neurosis. New York: International Universities Press.

Lewis, M., Sullivan, M. W., Stanger, C., \& Weiss, M. (1999). Self-development and self-conscious emotions. In A. Slater \& D. Muir (Eds.), The Blackwell reader in developmental psychology (343-359). Oxford: Blackwell.

Mead, G. H. (1934/1967). Mind, Self, and Society. C.W. Morris (Ed.). Chicago University Press.

Menesini, E., \& Camodeca, M. (2008). Shame and guilt as behaviour regulators: Relationships with bullying, victimization and prosocial behaviour. British Journal of Developmental Psychology, 26, 183-196. doi: 10.1348/026151007X205281

Olthof, T. (2012). Anticipated feelings of guilt and shame as predictors of early adolescents' antisocial and prosocial interpersonal behaviour. European Journal of Developmental Psychology, 9(3), 371-388. doi: 10.1080/17405629.2012.680300

Olthof, T., Ferguson, T. J., Bloemers, E., \& Deij, M. (2004). Morality- and identity-related antecedents of children's guilt and shame attributions in events involving physical illness. Cognition and Emotion, 18, 383-404. doi: 10.1080/02699930341000077

Quiles, Z. N. \& Bybee, J. (1997). Chronic and Dispositional Guilt: Relations to Mental Health, Prosocial Behavior, and Religiosity. Journal of Personality Assessment, 69, 104-126. doi: 10.1207/s15327752jpa6901_6 
Tangney, J. P. (1995). Shame and guilt in interpersonal relationships. In J. P. Tangney \& K. W. Fischer (Eds.), Self-conscious emotions: Shame, guilt, embarrassment, and pride (pp. 114139). New York: Guilford Press.

Tangney, J. P., Stuewig, J., \& Hafez, L. (2011). Shame, guilt, and remorse: Implications for offender populations. Journal of Forensic Psychiatry \& Psychology, 22(5), 706-723. doi: 10.1080/14789949.2011.617541

Tibbetts, S. G. (1997). Shame and rational choice in offending decisions. Criminal Justice \& Behavior, 24, 234-255. doi: 10.1177/0093854897024002006

Tikhomirov, O. K. (1984). Psihologija myshlenija [The psychology of thinking]. Moscow University Press.

Vygotsky, L. S. (1984). Sobranije sochinenij (Collected edition). V. $4^{\text {th }}$. Moscow: Pedagogika.

Wolf, S. T., Cohen, T. R., Panter, A. T., \& Insko, C. A. (2010). Shame proneness and guilt proneness: Toward the further understanding of reactions to public and private transgressions. Self \& Identity, 9(4), 337-362. doi: 10.1080/15298860903106843

Zahn-Waxler, C., \& Kochanska, G. (1990). The origins of guilt. In R. Thompson (Ed.), Nebraska symposium on Motivation: Vol.36. Socioemotional development (pp.183-258). Lincoln: University of Nebraska Press.

Received: 28 September 2013

Accepted: 01 November 2013

Available online: 15 December 2013 